\title{
Anti-HIV-I activity of anionic polymers: a comparative study of candidate microbicides
}

\author{
A Robert Neurath*, Nathan Strick and Yun-Yao Li
}

Address: Biochemical Virology Laboratory, The Lindsley F. Kimball Research Institute of the New York Blood Center, New York, NY 10021, USA

E-mail: A Neurath* - arneurath@worldnet.att.net; Nathan Strick - nathan_strick@nybc.org; Yun-Yao Li - yun-yao_li@nybc.org

${ }^{*}$ Corresponding author

Published: 21 November 2002

BMC Infectious Diseases 2002, 2:27

This article is available from: http://www.biomedcentral.com/I47I-2334/2/27

(C) 2002 Neurath et al; licensee BioMed Central Ltd. This is an Open Access article: verbatim copying and redistribution of this article are permitted in all media for any purpose, provided this notice is preserved along with the article's original URL.
Received: 14 August 2002

Accepted: 2I November 2002

\begin{abstract}
Background: Cellulose acetate phthalate (CAP) in soluble form blocks coreceptor binding sites on the virus envelope glycoprotein gp 20 and elicits gp 4 I six-helix bundle formation, processes involved in virus inactivation. CAP is not soluble at $\mathrm{pH}<5.5$, normal for microbicide target sites. Therefore, the interaction between insoluble micronized CAP and HIV-I was studied. Carbomer 974P/BufferGel; carrageenan; cellulose sulfate; dextran/dextrin sulfate, poly(napthalene sulfonate) and poly(styrene-4-sulfonate) are also being considered as anti-HIV-I microbicides, and their antiviral properties were compared with those of CAP.
\end{abstract}

Methods: Enzyme linked immunosorbent assays (ELISA) were used to (I) study HIV-I IIIB and BaL binding to micronized CAP; (2) detect virus disintegration; and (3) measure gP4I six-helix bundle formation. Cells containing integrated HIV-I LTR linked to the $\beta$-gal gene and expressing CD 4 and coreceptors CXCR4 or CCR5 were used to measure virus infectivity.

Results: I) HIV-I IIIB and BaL, respectively, effectively bound to micronized CAP. 2) The interaction between HIV-I and micronized CAP led to: (a) gP4I six-helix bundle formation; (b) virus disintegration and shedding of envelope glycoproteins; and (c) rapid loss of infectivity. Polymers other than CAP, except Carbomer 974P, elicited gP4I six-helix bundle formation in HIVI IIIB but only poly(napthalene sulfonate), in addition to CAP, had this effect on HIV-I BaL. These polymers differed with respect to their virucidal activities, the differences being more pronounced for HIV-I BaL.

Conclusions: Micronized CAP is the only candidate topical microbicide with the capacity to remove rapidly by adsorption from physiological fluids HIV-I of both the X4 and R5 biotypes and is likely to prevent virus contact with target cells. The interaction between micronized CAP and HIV-I leads to rapid virus inactivation. Among other anionic polymers, cellulose sulfate, BufferGel and aryl sulfonates appear most effective in this respect.

\section{Background}

Several anionic polymers were shown to have HIV-1 inhibitory activity and are being considered and evaluated as vaginal topical microbicides for prevention of transmis- sion of sexually transmitted disease (STD) pathogens, including HIV-1. These polymers belong to several classes: (1) sulfate esters of polysaccharides (dextrin and dextran sulfates [1-11]; cellulose sulfate [12-15]; sulfate esters of 
galactose $+3,6$-anhydrogalactose copolymers \{carrageenan; [1,16-19]\}); (2) polymers containing sulfonated benzene or naphthalene rings \{poly(styrene-4-sulfonate) $[20,21]\}$ and naphthalene sulfonate polymers $\{$ PRO2000 [22-24]\}; and (3) polycarboxylates (acrylic acid polymers \{Carbomer 974P; BufferGel [25-29]\}); and acetyl phthaloyl cellulose \{cellulose acetate phthalate (CAP) [30-37]\}.

The mechanisms involved in sexual transmission of HIV1 appear to be complex and are not yet fully defined $[38,39]$. Thus, a microbicide with HIV-1 inhibitory activity could provide protection in vivo only if both the compound and the virus reach susceptible cells before productive infection could occur. This might be difficult to accomplish. For this reason, it is preferable that microbicides irreversibly inactivate the virus upon the first compound/HIV-1 encounter in the vaginal environment, i.e. microbicides should have direct virucidal activity. Such activity was reported for dextran sulfate after $2 \mathrm{~h}$ incubation with HIV-1 [2] but results of other studies indicated that dextran sulfate failed to neutralize virus infectivity $[4,10]$. Inactivation of HIV-1 by carrageenan was reported in a review article [18]. BufferGel is virucidal against HIV1 by providing a buffered low $\mathrm{pH}$ environment $(\mathrm{pH} 3.9$ [25]), but virus inactivation might be incomplete and possibly compromised by minor $\mathrm{pH}$ increases due to the presence of seminal fluid [40]. To be effective in preventing infection by direct virus inactivation, anti-HIV-1 microbicides must be virucidal against both $\mathrm{X} 4$ and $\mathrm{R} 5$ viruses, utilizing CXCR4 and CCR5 as coreceptors [39,41], respectively, R5 HIV-1 being most frequently sexually transmitted. Recent results [36,37], (R. Shattock, personal communication) indicate that CAP in soluble form meets these requirements. Since CAP, unlike the other polymers listed above, is not soluble at low $\mathrm{pH}$, characteristic for a normal vaginal environment [42], micronized forms of CAP had to be used in microbicidal formulations of this compound [30-34]. Therefore, it was of interest to determine how CAP in micronized form and other candidate polymeric microbicides affect X4 and R5 viruses represented by HIV-1 IIIB and BaL, respectively.

\section{Methods \\ Reagents}

Aquateric (the micronized form of CAP containing $\approx$ $66 \%$ CAP and $\approx 34 \%$ of Poloxamer and distilled acetylated monoglycerides) was obtained from the FMC Corporation, Philadelphia, PA. Cellulose acetate phthalate (CAP) was a gift from Eastman Chemical Company, Kingsport, TN, and micronized using a SPEX 6800 freezer mill (SPEX CertiPrep, Metuchen, NJ) with the following settings: precooling time $10 \mathrm{~min}$, cooling time $1 \mathrm{~min}$, input frequency $15 ; 3$ cycles of 3 min each. The following additional polymers were obtained from commercial sources likely to be different from those for proprietary products being developed as microbicides: carrageenans $\kappa$ and $\lambda$ (Sigma, St. Louis, MO; mixed at a $1: 1(\mathrm{w} / \mathrm{w})$ ratio in all experiments); cellulose sulfate (Across Organics, Piscataway, NJ); dextran sulfate (M.W. 500,000; Pharmacia, Kalamazoo, MI); poly(naphthalene sulfonate) (BASF, Parsippany, NJ); poly(styrene-4-sulfonate) (Polysciences, Inc., Warrington, PA); and Carbomer 974P (B. F. Goodrich, Cleveland, $\mathrm{OH})$. Poloxamer $\{$ an $\alpha$-Hydro- $\gamma$-hydroxypoly(oxyethylene)poly(oxypropylene)poly(oxyethylene) block copolymer\} was from Spectrum, New Brunswick, NJ. Goat serum was from Atlanta Biologicals, Norcross, CA. BufferGel was a gift from Dr. Kevin J. Whaley, John Hopkins University. The mouse monoclonal antibody (mAb), NC1, raised against the gp 41 six/helix bundle from HIV-1 IIIB was prepared as described [43] and shown to react also with six-helix bundles from HIV-1 BaL [37]. Rabbit antibodies against the gp41 six-helix bundle and against HIV1 IIIB gp120 were prepared as described [44,45]. The latter antibodies were shown to crossreact with HIV-1 BaL gp120 [37]. Rabbit antibodies against HIV-1 tat as well as recombinant HIV-1 IIIB gp120 and biotinylated soluble CD4 (sCD4) were from ImmunoDiagnostics, Inc., Woburn, MA. Horseradish peroxidase (HRP) labeled streptavidin was from Zymed, South San Francisco, CA. HRP labeled goat anti-rabbit IgG was from Southern Biotechnology Associates, Inc., Birmingham, AL. HRP was quantitated using a kit from Kirkegaard \& Perry Laboratories, Inc., Gaithersburg, MD. Biotin labeled mouse IgG was obtained from the Roche Diagnostics Corporation, Indianapolis, IN. Recombinant protein A/G was from Pierce, Rockford, IL. Enzyme linked immunosorbent assay (ELISA) kits for the HIV-1 p24 antigen were from Beckman Coulter, Inc., Miami, FL. Pelletted, 1000-fold concentrates of HIV-1 IIIB $\left(6.8 \times 10^{10}\right.$ virus particles $\left./ \mathrm{ml}\right)$ and $\operatorname{BaL}\left(2.47 \times 10^{10}\right.$ virus particles $\left./ \mathrm{ml}\right)$ [46] were from Advanced Biotechnologies, Inc., Colombia, MD. Human seminal fluid was purchased from New England Immunology Associates, Cambridge, MA. HeLa-CD4-LTR- $\beta$-gal and MAGI-CCR5 cells were obtained from the AIDS Research and Reference Reagent Program contributed by Drs. M. Emerman and J. Overbaugh. Dulbecco's modified Eagle medium (DMEM) was from GIBCO $^{\mathrm{TM}}$ Invitrogen Corporation, Carlsbad, CA. The Galacto-Light Plus chemiluminescence reporter assay for $\beta$-galactosidase was from Applied Biosystems, Foster City, CA.

Citrate/phosphate buffers in the $\mathrm{pH}$ range of $2.9-5.0$ were prepared as described [47].

\section{Enzyme-linked immunosorbent assays (ELISA)}

The sandwich ELISA for gp41 six-helix bundles was performed as described [37,45]. HIV-1 IIIB and BaL virus preparations, respectively, treated with distinct anionic polymers, were precipitated with $3 \%$ polyethylene glycol 


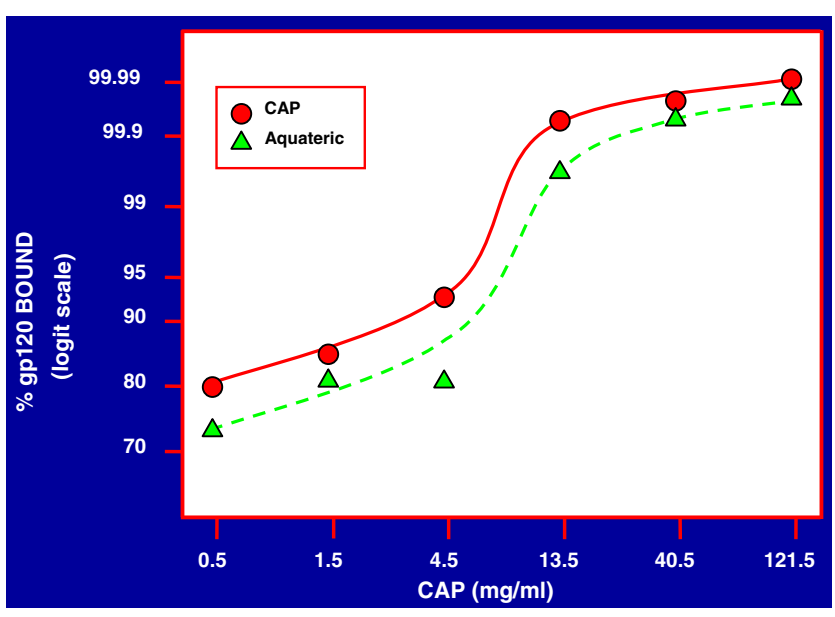

Figure I

Binding of HIV-I IIIB gPI20 to micronized CAP and Aquateric, respectively. Graded quantities of micronized CAP and Aquateric, respectively, in $0.5 \mathrm{ml}$ of $0.14 \mathrm{M} \mathrm{NaCl}$ were mixed with $100 \mu$ l of a solution containing I $\mu$ g of HIV-I IIIB gP I 20, and $10 \mu \mathrm{g}$ each of bovine serum albumin (BSA) and gelatin. After incubation for $5 \mathrm{~min}$ at $37^{\circ} \mathrm{C}$ the mixtures were cooled on ice, centrifuged at 10,000 rpm and the supernatant fluids were filtered through $0.45 \mu$ filters which had been prewashed with a solution containing $100 \mu \mathrm{g} / \mathrm{ml}$ of each BSA and gelatin in $0.14 \mathrm{M} \mathrm{NaCl}$. gP/20 in the filtrates was determined as described in the Methods section. The percentage of gPl20 recovered in the filtrates was determined from calibration curves relating absorbance readings to the concentration of $\mathrm{gP} / 20$.

6000 (PEG) in order to separate virus particles from excess compounds. The pellets were dissolved in lysis buffer $[1 \%$ Nonidet P40 \{NP40\}, $100 \mu \mathrm{g} / \mathrm{ml}$ bovine serum albumin (BSA) in phosphate buffered saline (PBS)], incubated for $30 \mathrm{~min}$ at $20^{\circ} \mathrm{C}$ and then added to wells coated with rabbit polyclonal antibodies to the gp41 core. Control virus was treated similarly. The lysis buffer was used as a safety precaution to minimize work with potentially infectious virus. Similar results were obtained when PBS was used for resuspension of virus particles instead of lysis buffer. After incubation at $4^{\circ} \mathrm{C}$ overnight, the bound six-helix bundles were detected by adding mAb NC-1 $(1 \mu \mathrm{g} / \mathrm{ml}$ in PBS $/ 1 \%$ $\mathrm{BSA} / 1 \%$ gelatin $\{100 \mu \mathrm{l} /$ well $\}$ for $1 \mathrm{~h}$ at $37^{\circ} \mathrm{C}$. Subsequently the wells were washed three times with PBS/ $0.05 \%$ Tween 20 , and biotin labeled anti-mouse IgG (100 $\mu \mathrm{l} /$ well; $125 \mathrm{ng} / \mathrm{ml}$ diluted in PBS containing $1 \%$ dry fatfree milk) was added. After incubation for $1 \mathrm{~h}$ at $37^{\circ} \mathrm{C}$ the wells were washed and HRP-streptavidin $(125 \mathrm{ng} / \mathrm{ml}$ in PBS containing $10 \%$ goat serum; $100 \mu \mathrm{l} /$ well) was added. After incubation for $1 \mathrm{~h}$ at $37^{\circ} \mathrm{C}$, the wells were washed six times with PBS/0.05\% Tween 20. Bound HRP was detected using the test kit from Kirkegaard \& Perry Laboratories following the manufacturer's protocol, and the absorbance was read at $450 \mathrm{~nm}$.
Recombinant gp120 HIV-1 IIIB in the presence of a 10fold excess of BSA and gelatin, respectively, was quantitated by adding the gp120/BSA/gelatin mixtures (before and after binding to micronized CAP or Aquateric; Fig. 1) at serial 5 -fold dilutions (2-fold to $3.9 \times 10^{6}$-fold in $0.14 \mathrm{M}$ NaCl-0.01 M Tris $\{$ TS $\}$ ) to 96-well polystyrene plates (Immulon II, Dynatech Laboratories, Inc. Chantilly, VA). After overnight incubation at $4^{\circ} \mathrm{C}$, the wells were washed and rabbit anti-gp120 (diluted 1:1,000 in 20\% goat serum $-0.05 \%$ Tween 20 in PBS pH 7.4) was added. After $2 \mathrm{~h}$ at $37^{\circ} \mathrm{C}$ the wells were washed and HRP labeled goat antirabbit IgG (diluted in $1 \%$ BSA $-0.25 \%$ gelatin $-0.05 \%$ Tween 20 in PBS pH 7.4; $\{250 \mathrm{ng} /$ well $\}$ ) was added. After $2 \mathrm{~h}$ at $37^{\circ} \mathrm{C}$ bound HRP was detected using the kit from Kirkegaard \& Perry Laboratories. The quantity of gp120 not adsorbed to CAP/Aquateric was determined from calibration curves relating absorbance readings to the concentration of gp120 not exposed to CAP/Aquateric.

The envelope glycoprotein gp120 released from HIV-1 BaL was quantitated as follows: Wells of polystyrene plates were first coated with protein $\mathrm{A} / \mathrm{G}(1 \mu \mathrm{g} /$ well $)$ in 0.1 $\mathrm{M}$ Tris buffer, $\mathrm{pH} 8.8$ for $2 \mathrm{~h}$ at $20^{\circ} \mathrm{C}$ followed by polyclonal rabbit anti-gp120 (diluted 500 -fold) for $1 \mathrm{~h}$ at $20^{\circ} \mathrm{C}$. Serial 2-fold dilutions in PBS containing 1\% BSA and 1\% gelatin (PBS-BG) of preparations containing gp120 were added to the wells. After $4 \mathrm{~h}$ at $20^{\circ} \mathrm{C}$ the wells were washed and bound gp120 was detected by addition of biotinyl sCD4 $(1 \mu \mathrm{g})$ followed by HRP streptavidin. Bound HRP was quantitated as described above. The experiments were done in triplicate.

\section{Measurements of HIV-I infectivity}

Two-fold serial dilutions of HIV-1 IIIB treated with distinct anionic polymers, and separated from these polymers by precipitation with 3\% PEG or by centrifugation at $14,000 \mathrm{rpm}$ for $1 \mathrm{~h}$, and control virus $(100 \mu \mathrm{l})$, respectively, were added to HeLa-CD4-LTR- $\beta$-gal cells which had been plated a day before infection in 96-well plates at $1 \times$ $10^{4}$ cells/well in $100 \mu \mathrm{l}$ of DMEM medium containing $10 \%$ fetal bovine serum (FBS). In some experiments, antiHIV-1 tat IgG $(25 \mu \mathrm{g})$ was added to treated and control virus to suppress the effect of extracellular tat, which may have been present in the virus preparations, on virus infection $[48,49]$. After incubation at $37^{\circ} \mathrm{C}$ for $48 \mathrm{~h}$, the culture supernatant fluids were removed and the cells washed once with PBS. Subsequently, $50 \mu \mathrm{l}$ of lysis buffer from the Galacto-Light Plus kit were added to the wells for $1 \mathrm{~h}$ at $20^{\circ} \mathrm{C}$. Aliquots $(20 \mu \mathrm{l})$ of the cell lysates were transferred into wells of 96-well microplates and $\beta$-galactosidase was quantitated using the Galacto-Light Plus System chemiluminescence reporter assay in a Microlight ML 2250 luminometer (Dynatech Laboratories, Inc. Chantilly, VA). The infectivity of treated and control HIV-1 BaL was measured 


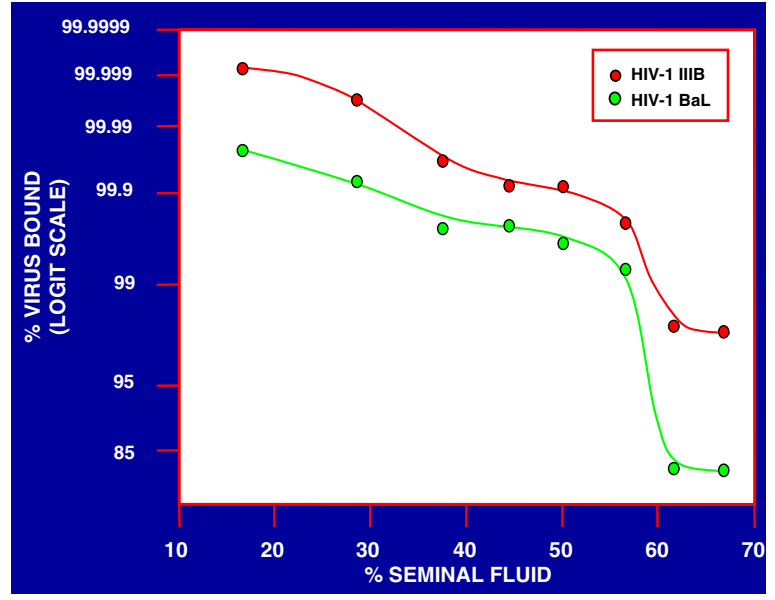

Figure 2

Binding of HIV-I IIIB and BaL, respectively, to Aquateric in the presence of human seminal fluid. Five hundred $\mu$ aliquots of a formulation containing Aquateric (18\% Aquateric, $6 \%$ hydroxypropyl methylcellulose, $76 \%$ glycerol) were mixed with graded volumes of seminal fluid (range: $100 \mu \mathrm{l}-1,000$ $\mu \mathrm{l})$ each containing equal amounts of purified HIV-I IIIB (6.8 $\times 10^{9}$ particles $)$ and $\mathrm{BaL}\left(2.5 \times 10^{9}\right.$ particles $)$, respectively. After incubation for $5 \mathrm{~min}$ at $37^{\circ} \mathrm{C}$ the mixtures were cooled in ice, centrifuged at $10,000 \mathrm{rpm}$ for $10 \mathrm{~min}$ in order to pellet Aquateric. The supernatant fluids were all adjusted to identical volumes ( $1.5 \mathrm{ml})$ and NP40 was added to a final concentration of $1 \%$. After incubation for $30 \mathrm{~min}$ at $37^{\circ} \mathrm{C}$, serial 5 fold dilutions $\left(\mathrm{I} / \mathrm{I}, 000\right.$ to $\left.\mathrm{I} / 3.9 \times 10^{8}\right)$ were prepared and $\mathrm{p} 24$ antigen in each dilution was measured by ELISA. The percentage of p24 antigen (representing a relative measure of the number of HIV-I virus particles) was determined from calibration curves relating absorbance readings to the concentration of p24 antigen.

by the same method except that MAGI-CCR5 cells were used.

Measurement of HIV-1 infectivity in seminal fluid is impeded by the cytotoxicity of seminal plasma [50,51]. contributed to by spermine [52]. Such effects were minimized by using for titrations of virus infectivity pellets after precipitation with 3\% PEG or after centrifugation $(14,000$ rpm for $1 \mathrm{~h}$ ).

\section{Results}

Micronized CAP induces gp4 I six-helix bundle formation and is virucidal against HIV-I

Earlier studies [36,37]. indicated that soluble CAP at neutral $\mathrm{pH}$ binds to the CXCR4 and CCR5 coreceptor binding sites on HIV-1 IIIB and BaL, respectively, and induced the formation of "dead-end" gp41 six-helix bundles. These two properties of soluble CAP appear to be involved in the virus inhibitory and virucidal activities of this compound. However, CAP is not soluble at < pH 5.5 and would pre- cipitate in a healthy human vaginal environment which is mildly acidic with a $\mathrm{pH}$ range of 3.5 - 4.5 [53]. The precipitate would have drastically reduced antiviral activity. To overcome this problem, CAP in a micronized form was used and proven to have virucidal activity against HIV-1 IIIB [31] and shown to be effective in reducing vaginal infection by simian immunodeficiency virus (SIV) in a macaque model [34]. Micronized CAP provides a low $\mathrm{pH}$ buffering system and this may have contributed to its virucidal properties. In order to correlate the properties of CAP in soluble and micronized forms, it was necessary to establish whether or not micronized CAP would bind HIV-1 virus particles and HIV-1 envelope glycoproteins, and induce the formation of gp41 six-helix bundles, a marker of irreversible virus inactivation, as did soluble CAP [37]. First it was established that HIV-1 gp120 bound to micronized CAP (provided in the form of micronized CAP particles or of a commercial product, "Aquateric", containing about $66 \%$ of CAP and used for enteric coating of tablets and capsules in the pharmaceutical industry [54]); (Fig. 1). Similar results were obtained when gp120 was diluted in seminal fluid (diluted $1: 1$ with $0.14 \mathrm{M} \mathrm{Na}$ $\mathrm{Cl}$ ). Under these conditions, $\geq 99.9997 \%$ of gp120 bound to micronized CAP and Aquateric (final concentration of CAP: $121.5 \mathrm{mg} / \mathrm{ml}$ ), respectively. HIV-1 IIIB and BaL virus particles also bound effectively in the presence of seminal fluid to Aquateric formulated into a topical gel (Fig. 2).

As a result of interaction with micronized CAP (in the form of Aquateric), the integrity of both HIV-1 IIIB and HIV-1 BaL virus particles was strikingly affected as indicated by the observation that most of the p24 antigen after virus contact with micronized CAP was no longer precipitable by 3\% polyethylene glycol 6000 (PEG) unlike p24 antigen within untreated virus particles which precipitates under these conditions (Fig. 3). Furthermore, interaction with micronized CAP elicited the formation of gp41 sixhelix bundles which were undetectable or present at low levels in untreated virus particles [37]. The six-helix bundles detectable by ELISA were mostly not precipitable by $3 \%$ PEG indicating that they were no longer associated with virus particles (Fig. 3). Furthermore, they were detected partially (HIV-1 IIIB) or entirely (HIV-1 BaL) in a form not bound anymore to the micronized CAP particles, unlike most of the virus-derived p24 antigen. This suggests that interaction of virus particles with micronized CAP resulted in stripping off of the viral envelopes which was more noticeable with HIV-1 BaL than with HIV-1 IIIB.

To confirm that gp41 six helix bundle formation was caused by contact of virus particles with the micronized form of CAP (= Aquateric) and not by low $\mathrm{pH}$ contributed by CAP, purified HIV-1 III B and BaL, respectively, was exposed for $5 \mathrm{~min}$ at $37^{\circ} \mathrm{C}$ to acidic buffers (final $\mathrm{pH}$ 2.9, $3.5,4.0,4.5$ and 5.0). The suspensions were neutralized 


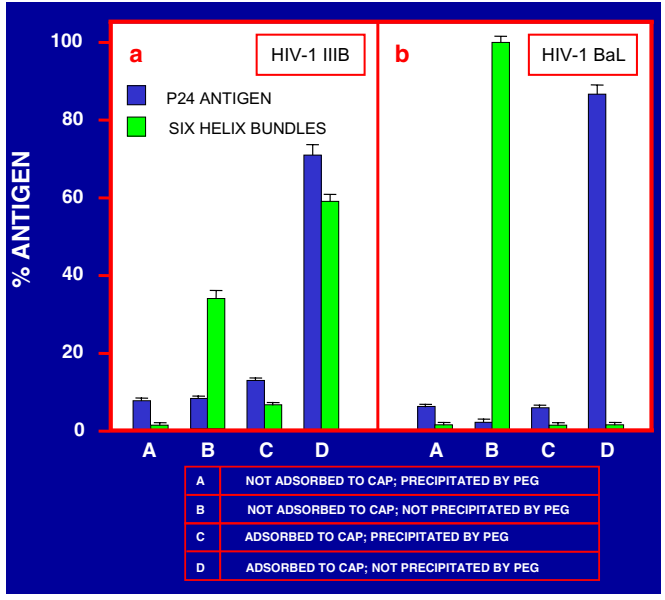

Figure 3

Aquateric causes the disintegration of HIV-I IIIB and BaL virus particles and induces the formation of gp4I six-helix bundles. Equal volumes of HIV-I IIIB and BaL virus preparations $\left(6.8 \times 10^{10}\right.$ and $2.47 \times 10^{10}$ virus particles, respectively, per $\mathrm{ml}$ ) and the Aquateric formulation (see legend to Fig. 2) were mixed and incubated for $5 \mathrm{~min}$ at $37^{\circ} \mathrm{C}$. Aquateric was pelletted by centrifugation at $10,000 \mathrm{rpm}$ for $10 \mathrm{~min}$ and the supernatant fluids were neutralized by addition of I $M$ $\mathrm{Na}_{2} \mathrm{HPO}_{4}$ and filtered through $0.45 \mu$ filters. The pellets containing Aquateric and adsorbed virus antigens were resuspended and brought to $\mathrm{pH} 7.0$ by addition of I $\mathrm{M} \mathrm{Na}_{3} \mathrm{HPO}_{4}$. The supernatant fluids and the resuspended pellets, respectively, were mixed with a solution of PEG 6000 (final concentration $3 \%$ ). The supernatant fluids and the resuspended pellets after PEG precipitation were mixed with NP40 (final concentration I\%). After incubation for $30 \mathrm{~min}$ at $37^{\circ} \mathrm{C}$ and $20^{\circ} \mathrm{C}$, respectively, p24 antigen and six-helix bundles in the supernatant fluids and resuspended pellets were measured by ELISA.

and assayed by ELISA for six-helix bundles. The results were negative (absorbance in the 0 to 0.068 range, the same as for viruses exposed to $\mathrm{pH} 7.0$ in the absence of CAP). Poloxamer, a constituent of Aquateric $(\leq 33 \%)$ at a final concentration of $30 \mathrm{mg} / \mathrm{ml}$ also did not induce the formation of six-helix bundles.

Results shown above indicated that HIV-1 adsorbed onto micronized CAP and that the CAP - virus interaction lead to the formation of gp 41 six-helix bundles, a hallmark for HIV-1 inactivation. [37] To confirm that contact of virus with micronized CAP leads to loss of HIV-1 infectivity, HIV-1 IIIB and BaL, respectively, were diluted in seminal fluid and the diluted virus preparations were mixed with an Aquateric formulation (for composition, see legend to Fig. 2) at volume ratios of $3: 1,1: 1$ and $1: 3$ for $5 \mathrm{~min}$ at $37^{\circ} \mathrm{C}$. Subsequently, the micronized Aquateric particles were sedimented by centrifugation. The supernatant fluids were brought to $\mathrm{pH} 7.0$ and the pellets were dissolved by addition of $\mathrm{Na}_{3} \mathrm{PO}_{4}$ (final $\mathrm{pH}=7.0$ ). All fractions were then precipitated by 3\% PEG and the redissolved pellets tested at 2- to 256-fold dilutions for infectivity (see Methods section). Infectious virus was undetectable ( $\geq 99.6 \%$ and $\geq 99.2 \%$ inactivation of HIV-1 IIIB and BaL, respectively). Similar results were obtained with other CAP formulations (data not shown).

\section{Induction of six-helix bundle formation by polymeric ani- onic candidate microbicides}

Since elicitation of gp41 six-helix bundles might be involved in, or contribute to the virucidal activity of candidate microbicides, it was of interest to determine whether anionic polymers other than CAP also induced six-helix bundle formation in HIV-1 IIIB and BaL virus particles.

Results in Fig. 4 show that carrageenan, cellulose sulfate, dextran sulfate, poly(napthalene sulfonate) and poly(styrene-4-sulfonate) all elicit gp41 six-helix bundle formation in HIV-1 IIIB but somewhat less effectively in comparison with CAP. On the other hand, Carbomer $974 \mathrm{P}$, the active ingredient in BufferGel, was inactive in this respect. Strikingly different results were obtained for HIV-1 BaL (Fig. 5), and show that only CAP and to a lesser extent poly(napthalene sulfonate) elicited gp41 six-helix bundles detectable by ELISA.

\section{Effect of anionic polymeric microbicide candidates on the integrity of HIV-I particles}

Since micronized CAP caused the dissociation of HIV-1 particles [31]; (Fig. 3), it was of interest to determine whether anionic polymeric candidate microbicides in soluble form at neutral $\mathrm{pH}$ would have similar effects. While no such effects were seen with HIV-1 IIIB, the integrity of HIV-1 BaL appeared to be partially diminished by treatment with CAP and drastically affected by cellulose sulfate (Fig. 6). The latter finding was confirmed by the observation that HIV-1 BaL gp120 was no longer precipitable by $3 \%$ PEG or pellettable by centrifugation after treatment of the virus with cellulose sulfate, unlike gp120 associated with untreated virus particles (Fig. 7). This was not seen with cellulose sulfate treated HIV-1 IIIB (data not shown).

\section{Comparative virucidal activity of polymeric anionic micro- bicide candidates}

HIV-1 IIIB and BaL, respectively, were treated with the distinct polymers $(10 \mathrm{mg} / \mathrm{ml})$ for $5 \mathrm{~min}$ at $37^{\circ} \mathrm{C}$ and the infectivity of the treated viruses was compared with that of control untreated HIV-1. In repeated experiments with HIV-1 IIIB, soluble and micronized CAP, cellulose sulfate, poly(naphthalene sulfonate), poly(styrene-4-sulfonate) and BufferGel, respectively, caused a $\geq 140$-fold reduction in infectivity, while dextran sulfate, carrageenan and Carbomer 974P ( $\mathrm{pH} 7$ ), respectively, were less effective (4- to 


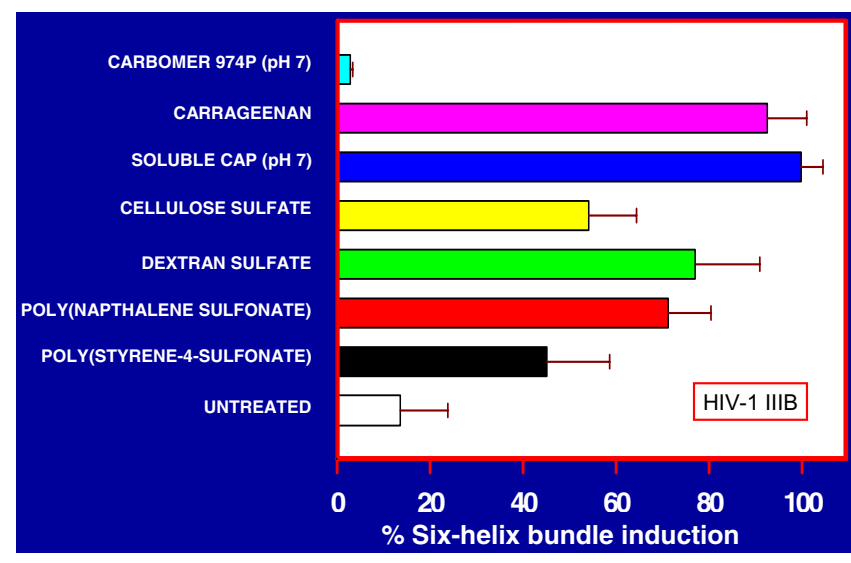

Figure 4

gP4I six-helix bundle induction in HIV-I IIIB by distinct anionic polymers representing candidate microbicides. Purified HIV-I IIIB $\left(7 \times 10^{9}\right.$ particles in TS) was precipitated with $3 \%$ PEG. The pellets were resuspended in $100 \mu \mathrm{l}$ of phosphate buffer saline (PBS) to separate the virus from soluble HIV-I antigens in the preparation. The different anionic polymers (listed on the ordinate) were added to a final concentration of $5 \mathrm{mg} / \mathrm{ml}$ except for Carbomer 974P $(2.5 \mathrm{mg} / \mathrm{ml})$. After incubation for $5 \mathrm{~min}$ at $37^{\circ} \mathrm{C}$, the mixtures were cooled in ice and PEG was added (final concentration 3\%). The pellets after centrifugation were washed once with $3 \%$ PEG in PBS, repelletted and finally resuspended in PBS containing $1 \%$ NP40 and $100 \mu \mathrm{g} / \mathrm{ml}$ BSA and incubated at $20^{\circ} \mathrm{C}$ for $30 \mathrm{~min}$. The formation of six-helix bundles was determined by ELISA (see Methods section). All experiments were done in triplicate, the absorbance readings are shown as percentages of the absorbance corresponding to six-helix bundles elicited by $\operatorname{CAP}(=100 \%)$.

25-fold reduction in infectivity). A typical example for HIV-1 IIIB is shown in Fig. 8.

Representative results shown in Fig. 9 indicate that the polymers differed from each other more substantially with respect to their capacity to inactivate HIV-1 BaL, micronized CAP, cellulose sulfate, BufferGel and the aryl sulfonates being most effective.

\section{Inhibitory effect of polymeric anionic microbicide candi- dates on blood clotting}

For the selection of the most promising candidate microbicides, it is important to compare not only their virus inhibitory and virucidal activities, but to also study their potential untoward effects. Since heparin and other anionic polymers are known to inhibit blood clotting [55], the effect of anionic polymeric microbicide candidates on blood clotting was measured. While CAP, carrageenan and BufferGel (Carbomer 974P) had moderate or no ef-

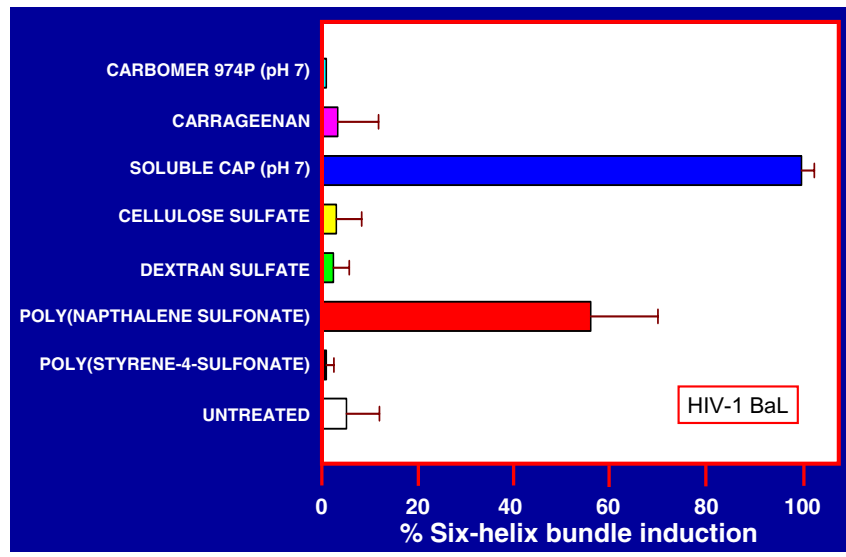

\section{Figure 5}

gp4 I six-helix bundle induction in HIV-I BaL by distinct anionic polymers respresenting candidate microbicides. Purified HIV-I BaL $\left(2.5 \times 10^{9}\right.$ particles in Dulbecco's modified Eagle medium $\{$ DMEM $\}+20 \%$ fetal bovine serum $\{$ FBS $\}$ ) were precipitated with $3 \%$ PEG and subsequently treated as described in the legend for Fig. 4.

fects, cellulose sulfate, dextran sulfate, poly(napthalene sulfonate) and poly(styrene-4-sulfonate) greatly inhibited clotting of ACD plasma (Fig. 10). The increase in clotting time might be potentially undesirable for topical applications under conditions of local preexisting injury or bleeding.

\section{Discussion}

Several anionic polymers are being considered as topical microbicides to prevent sexual transmission of HIV-1. They include: (1) sulfate esters of polysaccharides \{carrageenan [1,16-19], cellulose sulfate [12-15], and dextran or dextrin sulfate $[1-11]\} ;(2)$ aryl sulfonates $\{$ poly(naphthalene sulfonate) [22-24] and poly(styrene-4-sulfonate) $[20,21]\}$; and (3) aliphatic \{Carbomer 974P/BufferGel [25-29] $\}$ and aromatic carboxylates $\{$ CAP [30-37]\}. The anti-HIV-1 properties of these polymers are expected to depend on their complexation with virus proteins which is likely to occur mainly through the formation of salt linkages or ion pairs between oppositely charged groups on the polymers and virus proteins, respectively [56]. However, the anti-HIV-1 properties of these polymers may depend not only on their charge density, but also on the characteristics of their uncharged portions, which may be involved in hydrophobic and hydrogen bonding interactions which can elicit profound conformational changes in hydrophobic regions of proteins and cause disassembly of complex proteins consisting of subunits [57]. For these reasons it is not be expected that all anionic 


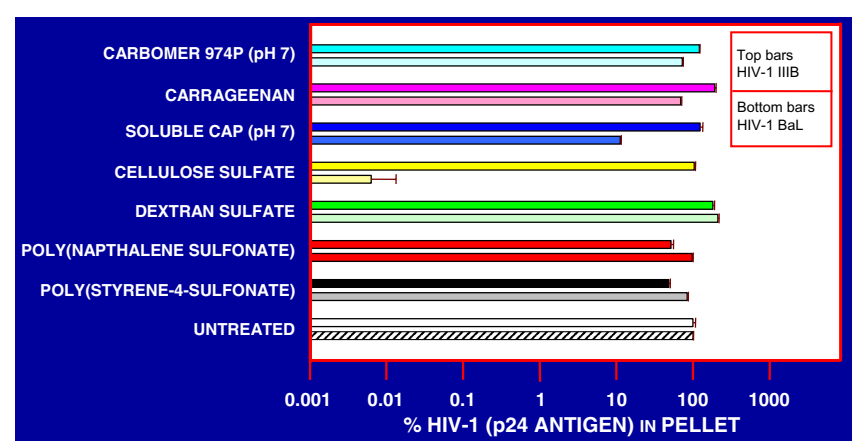

\section{Figure 6}

Effect of anionic polymeric microbicide candidates on the integrity of HIV-I IIIB and BaL virus particles. Purified HIV-I IIIB $\left(7 \times 10^{9}\right.$ particles $\left./ 100 \mu \mathrm{l}\right)$ and $\mathrm{BaL}\left(2.5 \times 10^{9}\right.$ particles $/ 100$ $\mu$ ) untreated or treated with the polymeric substances shown on the abscissa (final concentrations $5 \mathrm{mg} / \mathrm{ml}$ except for Carbomer 974P $\{2.5 \mathrm{mg} / \mathrm{ml}\})$ for $5 \mathrm{~min}$ at $37^{\circ} \mathrm{C}$. The mixtures were cooled on ice and the virus particles were pelletted by centrifugation ( $\mathrm{h}$ at $14,000 \mathrm{rpm}$ in a Beckman 54I5 $\mathrm{C}$ microfuge). The pellets were resuspended in lysis buffer ( $1 \% \mathrm{NP40}, 100 \mu \mathrm{g} / \mathrm{ml}$ BSA in PBS) and incubated for $30 \mathrm{~min}$ at $37^{\circ} \mathrm{C}$. p2 4 antigen was determined in serial dilutions of the lysates by ELISA. The levels of p24 antigen in the treated virus preparations were compared with those corresponding to lysed untreated virus (= $100 \%)$.

polymers, considered as anti-HIV-1 microbicides, would have similar biological activities.

In vivo protection by anti-HIV-1 compounds against sexual transmission of the virus could only be accomplished if the compounds at sufficient concentrations, and the virus both reach susceptible cells within genital mucosa before productive infection could occur $[38,39]$. Considering the complex events involved in sexual transmission of HIV-1, this might not be easily accomplished. Therefore, inactivation of HIV-1 infectivity preceding virus contact with susceptible target cells should be considered a preferred mechanism of protection against infection. For this reason it was of interest to study the virucidal activity of anionic polymeric microbicide candidates against both $\mathrm{X} 4$ (using CXCR4 as coreceptor) and R5 (using CCR5 as coreceptor) viruses, the latter being most frequently transmitted sexually [39].

Soluble CAP at neutral $\mathrm{pH}$ was shown to bind strongly to the coreceptor binding sites on gp120 of both X4 and R5 viruses [36] and to elicit the formation of gp41 six-helix bundles, the hallmark of irreversible virus inactivation [37]. Thus, HIV-1 exposed to CAP at sufficient concentra-

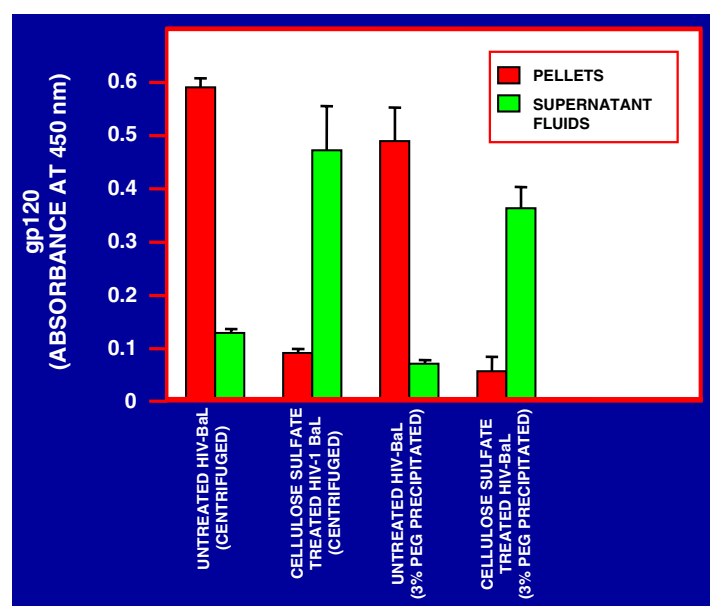

Figure 7

Release of gp I 20 from HIV-I BaL by treatment with cellulose sulfate. Purified HIV-I BaL $\left(2.5 \times 10^{9}\right.$ particles/I00 $\left.\mu \mathrm{l}\right)$ was treated with cellulose sulfate (final concentration $5 \mathrm{mg} / \mathrm{ml}$ ) for $5 \mathrm{~min}$ at $37^{\circ} \mathrm{C}$. The mixture was cooled in ice and divided into 2 aliquots. One aliquot was centrifuged for I h at 14,000 rpm and the $2^{\text {nd }}$ aliquot was precipitated with PEG 6000 (final concentration 3\%). gPl 20 in the respective supernatant fluids and pellets (resuspended in PBS) was determined by ELISA as described [37]; (see Methods section).

tions is rendered noninfectious, and continued presence of CAP is not required to maintain lack of infectivity. CAP differs from all other anionic polymers listed above, in that it is not soluble at $\mathrm{pH}<5.5$. Therefore, CAP would be expected to precipitate in a normal acidic vaginal environment. To avoid this, CAP in micronized form (which does not aggregate at low $\mathrm{pH}$ ), instead of CAP in soluble form is being considered as a topical microbicide [30-35]. Micronized CAP (Aquateric) was shown to be virucidal against HIV-1, herpesviruses and several nonviral sexually transmitted disease (STD) pathogens [30-34]. The virucidal activity of micronized CAP could at least partly be explained by its buffering capacity at low $\mathrm{pH}$ [40] since it is a free acid while other anionic polymeric microbicide candidates (except BufferGel, the active ingredient of which is Carbomer 974P [27]) are sodium salts. Results presented here explain how micronized CAP inactivates HIV-1. Both the envelope glycoprotein gp120 (Fig. 1) and HIV-1 IIIB and BaL virus particles (Fig. 2) in the presence of an excess of nonviral proteins, including seminal fluid, bind effectively to micronized CAP. Under in vivo conditions (when the virus concentrations are by one to four orders of magnitude lower than those used here under experimental conditions [58,59], (Fig. 2)), this would be expected to physically remove virus particles by adsorption onto micronized CAP (Aquateric) so that they would cease to be available to initiate the complex sequence of events leading to mucosal infection. Furthermore, interac- 


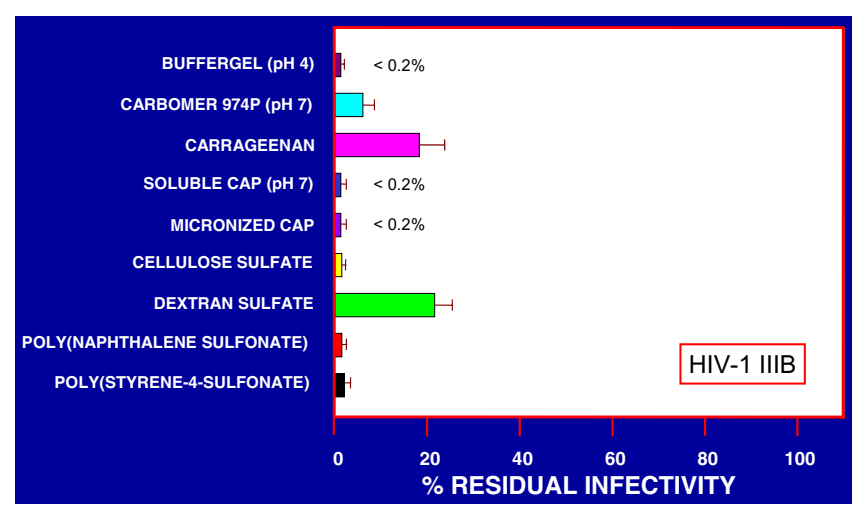

Figure 8

Inactivation of HIV-I IIIB by polymeric anionic candidate microbicides. HIV-I IIIB $\left(7 \times 10^{9}\right.$ virus particles/I00 $\left.\mu \mathrm{l}\right)$ was treated with the compounds indicated on the abscissa (final concentrations $10 \mathrm{mg} / \mathrm{ml}$ except for Carbomer 974P [2.5 mg/ $\mathrm{ml}$; neutralized to $\mathrm{pH}$ 7.0; at higher concentrations the solutions became too viscous to handle]) for $5 \mathrm{~min}$ at $37^{\circ} \mathrm{C}$. The final dilution of BufferGel was 4-fold (final $\mathrm{pH}=4.0$ ). The preparations were cooled on ice and virus particles were separated from the polymers and their infectivity determined as described in the Methods section. For comparison, results obtained with a formulation of micronized CAP (= Aquateric; see legend for Fig. 2) are shown.

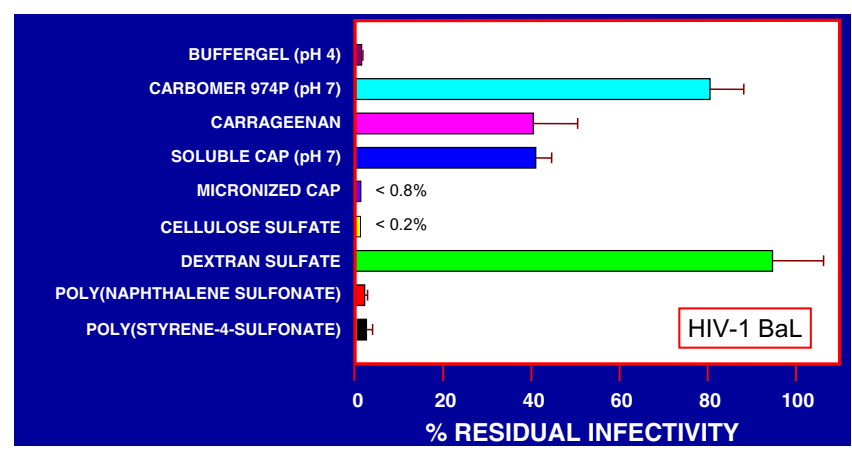

Figure 9

Inactivation of HIV-I BaL by polymeric anionic candidate microbicides. HIV-I BaL $\left(2.5 \times 10^{9}\right.$ virus particles/I00 $\left.\mu \mathrm{I}\right)$ was treated as described in the legend for Fig. 8.

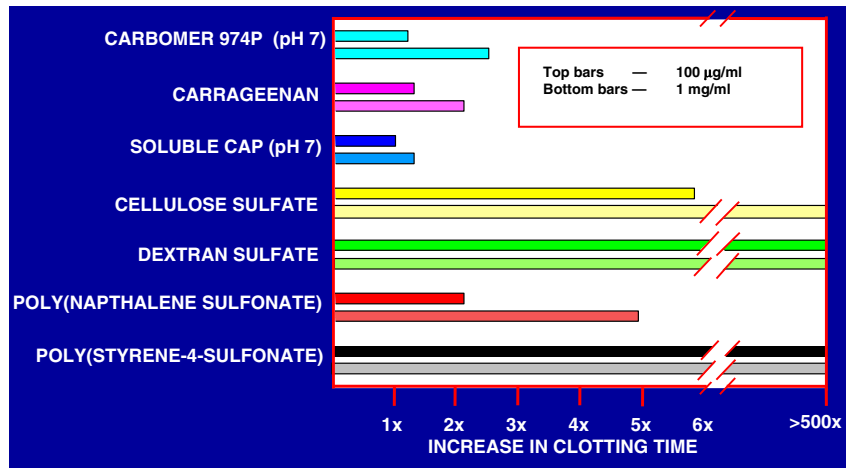

\section{Figure 10}

Effect of polymeric anionic candidate microbicides on clotting of ACD plasma. The compounds indicated on the abscissa (final concentrations of 100 and $1000 \mu \mathrm{g} / \mathrm{ml}$, respectively) were added to fresh citrated plasma prewarmed to $37^{\circ} \mathrm{C}$. $\mathrm{CaCl}_{2}$ was added to a final concentration of $10 \mathrm{mM}$, and the time when clot formation had started was measured. The increase in clotting time as compared with the time required for clotting of plasma in the absence of any added compounds is shown.

tion with micronized CAP elicits the formation of gp41 six-helix bundles and causes the stripping off of HIV-1 envelope glycoproteins (Fig. 3). The formation of gp41 sixhelix bundles was not due to exposure to a low $\mathrm{pH}$ environment provided by the micronized CAP, since exposure to low $\mathrm{pH}$ buffers did not elicit gp41 six-helix bundle formation. In summary, the contact of HIV-1 IIIB and HIV-1 $\mathrm{BaL}$, representatives of $\mathrm{X} 4$ and $\mathrm{R} 5$ viruses respectively, with micronized CAP, resulted in a complex sequence of events involving virus adsorption, exposure to low $\mathrm{pH}$, induction of gp41 six-helix bundles, and stripping off of viral envelopes and virus disintegration, ultimately resulting in loss of infectivity.

In order to contribute to the understanding of the potential virucidal activity of anionic polymers, their capacity to induce gp41 six-helix bundle formation was measured and compared with that of CAP in soluble form (pH 7.0). All polymers except Carbomer 974P elicited gp41 six-helix bundle formation in HIV-1 IIIB, albeit in some cases less efficiently in comparison with CAP (Fig. 4). On the other hand, gp41 six-helix bundle formation in HIV-1 BaL was detectable only for CAP and poly(naphthalene sulfonate) treated virus (Fig. 5) suggesting differences among the anionic polymers with respect to their activity against the R5 virus HIV-1 BaL. The induction of six-helix bundles in HIV-1 does not seem to be the only mechanism involved in virucidal activity of anionic polymers (compare 
Fig. 5 with Figs. 8 and 9) and there might be other contributing processes.

Since CAP in micronized form was shown to cause disintegration of HIV-1 virus particles [31], (Fig. 3), it was of interest to determine whether any of the other anionic polymeric microbicide candidates affect the integrity of virus particles. While HIV-1 IIIB was not affected significantly by any of the polymers tested, CAP to some extent, but surprisingly cellulose sulfate affected the integrity of HIV1 BaL particles (Fig. 6). These results were supported by the observation that HIV-1 BaL gp120 after treatment with cellulose sulfate, unlike virus associated gp120, did not become precipitated with 3\% PEG and failed to pellet by centrifugation under conditions leading to sedimentation of intact virus particles (Fig. 7)]. The differential sensitivity of an R5 virus, HIV-1 BaL, as compared to an R4 virus, HIV-1 IIIB, to the same negatively charged polyelectrolyte appears unprecedented to the best of our knowledge.

Among the three polysaccharide sulfate esters (carrageenan, cellulose sulfate and dextran sulfate), cellulose sulfate appeared to be more effective against HIV-1 BaL than the other polymers. This might be due to the polysaccharide backbone of cellulose [60] with a propensity to form strong intermolecular hydrogen bonds and to be involved in hydrophobic interactions more than soluble dextrans [61] and galactose $+3,6$-anhydrogalactose copolymers (= the saccharide moiety of carrageenan) $[62,63]$. Among the two polymers containing aryl sulfonates, poly(napthalene sulfonate) was more effective than poly(styrene-4-sulfonate) with respect to induction of gp41 six-helix bundles in HIV-1 BaL. This difference may possibly be due to the high propensity of the uncharged part of the molecule \{poly(naphtalene) $\}$ to be involved in hydrophobic interactions. Among the two carboxylate polymers (Carbomer 974P and CAP), only soluble CAP (at neutral $\mathrm{pH}$ ) was able to elicit the formation of gp41 six-helix bundles in both HIV-1 IIIB and BaL and was virucidal against both of these viruses. The insoluble, micronized form of CAP had similar properties. The differences in biological activities of these polymers is probably due to their noncharged portions, i.e. mainly the occurrence of benzene rings in CAP.

Polycarboxylates (soluble CAP and Carbomer 974P; Fig. 10) had a minimal effect on plasma coagulation. Among the sulfonates and polysaccharide sulfates, carrageenan and poly(napthalene sulfonate) had lower anti-coagulant activity in comparison with cellulose sulfate, dextran sulfate and poly(styrene-4-sulfonate) (Fig. 10). Consideration of these side effects might contribute to the process of selection of preferred microbicides for future large-scale use.

\section{Conclusions}

Among anionic polymers considered as topical microbicides to prevent sexual transmission of HIV-1 \{Carbomer 974P/BufferGel, carrageenan, CAP, cellulose sulfate, dextran/dextrin sulfate, poly(napthalene sulfonate) and poly(styrene-4-sulfonate) $\}$, CAP formulated in a micronized form, is the only compound which has a capacity to remove from physiological fluids infectious virus by adsorption onto the micronized particles. The interaction between HIV-1 IIIB, a representative of X4 viruses, and HIV-1 BaL, a representative of $\mathrm{R} 5$ viruses, with the micronized form of CAP has the following consequences: 1) elicitation of "dead-end" gp41 six-helix bundles expected to render the virus incompetent to fuse with target cells; 2 ) loss of virus integrity and stripping off of the envelope glycoproteins; and 3) inactivation of virus infectivity. Elicitation of gp41 six-helix bundles and virucidal activity represent shared properties between micronized and soluble (at sufficient concentrations) forms of CAP [37].

As determined by ELISA, the aforementioned polymers other than CAP (except Carbomer 974P) also elicited gp41 six-helix bundle formation in HIV-1 IIIB, albeit less effectively than CAP. On the other hand, only poly(napthalene sulfonate), in addition to CAP, elicited detectable six-helix bundle formation in HIV-1 BaL. This suggests that $\mathrm{X} 4$ and $\mathrm{R} 5$ viruses may be differently affected by some of the polymeric compounds being considered as topical microbicides. This was confirmed by the results of assays for virucidal activity.

\section{Abbreviations used}

$\mathrm{ACD}$, acid citrate dextrose; $\mathrm{CAP}$, cellulose acetate phthalate; BSA, bovine serum albumin; DMEM, Dulbecco's modified Eagle medium; ELISA, enzyme-linked immunosorbent assay; FBS, fetal bovine serum; HIV-1, human immunodeficiency virus type 1 ; HRP, horseradish peroxidase; $\mathrm{mAb}$, monoclonal antibodies; PEG 6000, polyethylene glycol 6000; PBS, phosphate buffered saline; PBS-BG, 1\% BSA/1\% gelatin in PBS; sCD4, soluble CD4; STD, sexually transmitted disease; TS, $0.14 \mathrm{M} \mathrm{NaCl}, 0.01$ M Tris, pH 7.0;

\section{Competing interests}

None declared

\section{Authors' contributions}

Author 1 ARN developed the concepts representing the basis of the manuscript and designed most experiments. Author 2 NS carried out most experiments and contributed to the development of experimental techniques. Author 3 YYL did all the tissue culture work and infectivity assays. 


\section{Acknowledgements}

We thank Ms. V. Kuhlemann for preparation of the manuscript and figures, Dr. S. Jiang and Dr. A. K. Debnath for comments and Dr. K. J. Whaley and Dr. S. Jiang for providing BufferGel and mAb NC-I, respectively. This study was supported by $\mathrm{NIH}$ grant (POI HD4I76I) and the Marilyn M. Simpson Charitable Trust.

\section{References}

I. Baba M, Snoeck R, Pauwels R, De Clercq E: Sulfated polysaccharides are potent and selective inhibitors of various enveloped viruses, including herpes simplex virus, cytomegalovirus, vesicular stomatitis virus, and human immunodeficiency virus. Antimicrob Agents Chemother 1988, 32:1742-1745

2. Bagasra O, Lischner HW: Activity of dextran sulfate and other polyanionic polysaccharides against human immunodeficiency virus. J Infect Dis 1988, I 58: 1084-1087

3. Baba M, Schols D, Pauwels R, Nakashima H, De Clercq E: Sulfated polysaccharides as potent inhibitors of HIV-induced syncytium formation: A new strategy towards AIDS chemotherapy. J Acquir Immune Defic Syndr 1990, 3:493-499

4. McClure MO, Moore JP, Blanc DF, Scotting P, Cook GM, Keynes RJ, Weber JN, Davies D, Weiss RA: Investigations into the mechanism by which sulfated polysaccharides inhibit HIV infection in vitro. AIDS Res Hum Retroviruses 1992, 8:19-26

5. Lynch G, Low L, Li S, Sloane A, Adams S, Parish C, Kemp B, Cunningham AL: Sulfated polyanions prevent HIV infection of lymphocytes by disruption of the CD4-gp I 20 interaction, but do not inhibit monocyte infection. J Leukoc Biol 1994, 56:266-272

6. Shaunak S, Gooderham NJ, Edwards RJ, Payvandi N, Javan CM, Baggett N, MacDermot J, Weber JN, Davies DS: Infection by HIV-I blocked by binding of dextrin 2-sulphate to the cell surface of activated human peripheral blood mononuclear cells and cultured T-cells. Br J Pharmacol I994, I I 3: 15 I- I58

7. Davies DS: Dextrin sulfates as anti HIV-I agents and composition thereof. US Patent 5,439,892

8. Javan CM, Gooderham NJ, Edwards RJ, Davies DS, Shaunak S: AntiHIV type I activity of sulfated derivatives of dextrin against primary viral isolates of HIV type $I$ in lymphocytes and monocyte-derived macrophages. AIDS Res Hum Retroviruses 1997, I 3:875-880

9. Stafford MK, Cain D, Rosenstein I, Fontaine EA, McClure M, Flanagan AM, Smith JR, Taylor-Robinson D, Weber J, Kitchen VS: A placebocontrolled, double-blind prospective study in healthy female volunteers of dextrin sulphate gel: A novel potential intravaginal virucide. J Acquir Immune Defic Syndr Hum Retrovirol 1997, 14:213-218

10. Baba M, Pauwels R, Balzarini J, Arnout J, Desmyter J, De Clerca E: Mechanism of inhibitory effect of dextran sulfate and heparin on replication of human immunodeficiency virus in vitro. Proc Natl Acad Sci U S A 1988, 85:6132-6136

II. Rosenstein IJ, Stafford MK, Kitchen VS, Ward H, Weber JN, TaylorRobinson D: Effect on normal vaginal flora of three intravaginal microbicidal agents potentially active against human immunodeficiency virus type I. J Infect Dis 1998, I77:1386-1390

12. Yamamoto I, Takayama K, Honma K, Gonda T, Matsuzaki K, Hatanaka K, Uryu T, Yoshida O, Nakashima H, Yamamoto N, et al: Synthesis, structure and antiviral activity of sulfates of cellulose and its branched derivatives. Carbohydrate Polymers 1991, 14:53-63

13. Anderson RA, Zaneveld LJD, Usher TC: Cellulose sulfate for use as antimicrobial and contraceptive agent. US Patent 6,063,773

14. Mauck C, Frezieres R, Walsh T, Robergeau K, Callahan M: Cellulose sulfate: tolerance and acceptability of penile application. Contraception 200I, 64:377-38I

15. Mauck C, Weiner DH, Ballagh S, Creinin M, Archer DF, Schwartz J, Pymar H, Lai JJ, Callahan M: Single and multiple exposure tolerance study of cellulose sulfate gel: a Phase I safety and colposcopy study. Contraception 200I, 64:383-39I

16. Carlucci MJ, Pujol CA, Ciancia M, Noseda MD, Matulewicz MC, Damonte EB, Cerezo AS: Antiherpetic and anticoagulant properties of carrageenans from the red seaweed Gigartina skottsbergii and their cyclized derivatives: correlation between structure and biological activity. Int J Biol Macromol I997, 20:97-105

17. Coggins C, Blanchard K, Alvarez F, Brache V, Weisberg E, Kilmarx PH, Lacarra M, Massai R, Mishell D Jr, Salvatierra A, et al: Prelimi- nary safety and acceptability of a carrageenan gel for possible use as a vaginal microbicide. Sex Transm Infect 2000, 76:480483

18. Schaeffer DJ, Krylov VS: Anti-HIV activity of extracts and compounds from algae and cyanobacteria. Ecotoxicol Environ Saf 2000, 45:208-227

19. Maguire RA, Bergman N, Phillips DM: Comparison of microbicides for efficacy in protecting mice against vaginal challenge with herpes simplex virus type $\mathbf{2}$, cytotoxicity, antibacterial properties, and sperm immobilization. Sex Transm Dis 200I, 28:259-265

20. Anderson RA, Feathergill K, Diao X, Cooper M, Kirkpatrick R, Spear P, Waller DP, Chany C, Doncel GF, Herold B, et al: Evaluation of poly(styrene-4-sulfonate) as a preventive agent for conception and sexually transmitted diseases. J Androl 2000, 21:862875

21. Christensen ND, Reed CA, Culp TD, Hermonat PL, Howett MK, Anderson RA, Zaneveld LJ: Papillomavirus microbicidal activities of high-molecular-weight cellulose sulfate, dextran sulfate, and polystyrene sulfonate. Antimicrob Agents Chemother 200I, 45:3427-3432

22. Rusconi S, Moonis M, Merrill DP, Pallai PV, Neidhardt EA, Singh SK, Willis KJ, Osburne MS, Profy AT, Jenson JC, et al: Naphthalene sulfonate polymers with CD4-blocking and anti-human immunodeficiency virus type I activities. Antimicrob Agents Chemother 1996, 40:234-236

23. Van Damme L, Wright A, Depraetere K, Rosenstein I, Vandersmissen V, Poulter L, McKinlay M, Van Dyck E, Weber J, Profy A, et al: A phase I study of a novel potential intravaginal microbicide, PRO2000 in healthy sexually inactive women. Sex Transm Dis 2000, 76: $126-130$

24. Weber J, Nunn A, O'Connor T, Jeffries D, Kitchen V, McCormack S, Stott J, Almond N, Stone A, Darbyshire J: 'Chemical condoms' for the prevention of HIV infection: evaluation of novel agents against SHIV $_{89.6 P D}$ in vitro and in vivo. AIDS 200I, I 5: I563-I568

25. Olmsted SS, Dubin NH, Cone RA, Moench TR: The rate at which human sperm are immobilized and killed by mild acidity. Fertil Steril 2000, 73:687-693

26. Clarke JG, Peipert JF, Hillier SL, Heber W, Boardman L, Moench TR, Mayer K: Microflora changes with the use of a vaginal microbicide. Sex Transm Dis 2002, 29:288-293

27. Zeitlin L, Hoen TE, Achilles SL, Hegarty TA, Jerse AE, Kreider JW, OImsted SS, Whaley KJ, Cone RA, Moench TR: Tests of BufferGel for contraception and prevention of sexually transmitted diseases in animal models. Sex Transm Dis 200I, 28:417-423

28. Mayer KH, Peipert J, Fleming T, Fullem A, Moench T, Cu-Uvin S, Bentley M, Chesney M, Rosenberg Z: Safety and tolerability of BufferGel, a novel vaginal microbicide, in women in the United States. Clin Infect Dis 200I, 32:476-482

29. van de Wijgert J, Fullem A, Kelly C, Mehendale S, Rugpao S, Kumwenda N, Chirenje Z, Joshi S, Taha T, Padian N, et al: Phase I trial of the topical microbicide BufferGel: Safety results from four international sites. J Acquir Immune Defic Syndr 200I, 26:2 I-27

30. Gyotoku T, Aurelian L, Neurath AR: Cellulose acetate phthalate (CAP): an 'inactive' pharmaceutical excipient with antiviral activity in the mouse model of genital herpesvirus infection. Antivir Chem Chemother 1999, 10:327-332

31. Neurath AR, Strick N, Li Y-Y, Lin K, Jiang S: Design of a "microbicide" for prevention of sexually transmitted diseases using "inactive" pharmaceutical excipients. Biologicals 1999, 27:II-2I

32. Neurath $A R, L i ~ Y Y$, Mandeville $R$, Richard $L$ : In vitro activity of a cellulose acetate phthalate topical cream against organisms associated with bacterial vaginosis. J Antimicrob Chemother 2000, 45:7|3-7|4

33. Neurath AR: A microbicide for prevention of sexually transmitted diseases using a pharmaceutical excipient. AIDS Patient Care STDS 2000, 14:215-219

34. Manson KH, Wyand MS, Miller C, Neurath AR: The effect of a cellulose acetate phthalate topical cream on vaginal transmission of simian immunodeficiency virus in rhesus monkeys. Antimicrob Agents Chemother 2000, 44:3199-3202

35. Kawamura T, Cohen SS, Borris DL, Aquilino EA, Glushakova S, Margolis LB, Orenstein JM, Offord RE, Neurath AR, Blauvelt A: Candidate microbicides block HIV-I infection of human immature Langerhans cells within epithelial tissue explants. J Exp Med 2000, 192:|49|-1500 
36. Neurath AR, Strick N, Li YY, Debnath AK: Cellulose acetate phthalate, a common pharmaceutical excipient, inactivates HIV-I and blocks the coreceptor binding site on the virus envelope glycoprotein gp I 20. BMC Infect Dis 200I, I:I7

37. Neurath AR, Strick N, Jiang S, Li YY, Debnath AK: Anti-HIV-I activity of cellulose acetate phthalate: Synergy with soluble CD4 and induction of "dead-end" gp4 I six-helix bundles. BMC Infect Dis 2002, 2:6

38. Greenhead P, Hayes P, Watts PS, Laing KG, Griffin GE, Shattock RJ: Parameters of human immunodeficiency virus infection of human cervical tissue and inhibition by vaginal virucides. $\mathrm{Vi-}$ rol 2000, 74:5577-5586

39. Shattock RJ, Doms RW: AIDS models: Microbicides could learn from vaccines. Nat Med 2002, 8:425

40. O'Connor TJ, Kinchington D, Kangro HO, Jeffries DJ: The activity of candidate virucidal agents, low $\mathrm{pH}$ and genital secretions against HIV-I in vitro. Int J STD AIDS 1995, 6:267-272

4I. Berger EA, Doms RW, Fenyo EM, Korber BT, Littman DR, Moore JP, Sattentau QJ, Schuitemaker H, Sodroski J, Weiss RA: A new classification for HIV-I. Nature 1998, 39 I:240

42. Larsen B: Vaginal flora in health and disease. Clin Obstet Gynecol |993, 36: $|07-| 2 \mid$

43. Jiang S, Lin K, Lu M: A conformation-specific monoclonal antibody reacting with fusion-active gp4I from the human immunodeficiency virus type I envelope glycoprotein. J Virol 1998, 72:10213-10217

44. Neurath AR, Strick N, Li Y-Y, Jiang S: Improbability of harmful autoimmune responses resulting from immunization with HIV-I envelope glycoproteins. AIDS Res Hum Retroviruses 1993, 9:1195-1208

45. Jiang S, Lin $\mathrm{K}$, Zhang $\mathrm{L}$, Debnath $\mathrm{AK}$ : A screening assay for antiviral compounds targeted to the HIV-I gp4I core structure using a conformation-specific monoclonal antibod $/$ Virol Methods 1999, 80:85-96

46. Gartner S, Markovits P, Markovitz DM, Kaplan MH, Gallo RC, Popovic $M$ : The role of mononuclear phagocytes in HTLV-III/LAV infection. Science 1986, 233:215-219

47. Stoll VS, Blanchard JS: Buffers: Principles and Practice In Methods in Enzymology, Guide to Protein Purification (Edited by: Deutscher MP) San Diego, CA., Academic Press, Inc 1990, I 82:24-38

48. Huang L, Bosch I, Hofmann W, Sodroski J, Pardee AB: Tat protein induces human immunodeficiency virus type I (HIV-I) coreceptors and promotes infection with both macrophage-tropic and T-lymphotropic HIV-I strains. J. Virol 1998, 72:8952-8960

49. Secchiero P, Zella D, Capitani S, Gallo RC, Zauli G: Extracellular HIV-I tat protein up-regulates the expression of surface CXC-chemokine receptor 4 in resting CD4+ T cells. I Immunol |999, |62:2427-243|

50. Rasheed S, Li Z, Xu D: Human immunodeficiency virus load. Quantitative assessment in semen from seropositive individuals and in spiked seminal plasma. J Reprod Med 1995, 40:747757

51. Krieger JN, Coombs RW, Collier AC, Ho DD, Ross SO, Zeh JE, Corey L: Intermittent shedding of human immunodeficiency virus in semen: implications for sexual transmission. J Urol I995, 1 54:1035-1040

52. Allen RD, Roberts TK: Role of spermine in the cytotoxic effects of seminal plasma. Am J Reprod Immunol Microbiol I987, 13:4-8

53. Masters W, Johnson V: Sexual physiology and AIDS protection. In AIDS and Sex (Edited by: Voeller B, Reinisch J, Gottlieb M) New York, Oxford University Press 1990, 37I-374

54. Goskonda SR, Lee JC: Cellulose Acetate Phthalate. In Handbook of Pharmaceutical Excipients (Edited by: Kibbe AH, Washington, DC) American Pharmaceutical Association 2000, 99-101

55. de Raucourt E, Mauray S, Chaubet F, Maiga-Revel O, Jozefowicz M, Fischer AM: Anticoagulant activity of dextran derivatives. $\mathrm{Bi}$ omed Mater Res 1998, 41:49-57

56. Izumi T, Hirata M: Complexation of papain with strong polyanions and enzymatic activities of the resulting complexes. Macromol Sci, Pure Appl Chem I994, A3 I (I):39-5 I

57. Sedlak E, Antalik M: Coulombic and noncoulombic effect of polyanions on cytochrome c structure. Biopolymers 1998, 46: $145-154$

58. Dyer JR, Kazembe P, Vernazza PL, Gilliam BL, Maida M, Zimba D, Hoffman IF, Royce RA, Schock JL, Fiscus SA, et al: High levels of human immunodeficiency virus type $I$ in blood and semen of seropositive men in sub-Saharan Africa. I Infect Dis 1998, 177:1742-1746

59. Chakraborty H, Sen PK, Helms RW, Vernazza PL, Fiscus SA, Eron JJ, Patterson BK, Coombs RW, Krieger JN, Cohen MS: Viral burden in genital secretions determines male-to-female sexual transmission of HIV-I: a probabilistic empiric model. AIDS 200I, I5:62I-627

60. Kadla JF, Gilbert RD: Cellulose structure: A review. Cellulose Chemistry and Technology 2000, 34:197-216

61. Cheetham NWH, Fiala-Beer E: Dextran structural details from high-field proton NMR spectroscopy. Carbohydrate Polymers 1991, 14:149-158

62. Reilly WJ Jr: Carrageenan. In Handbook of Pharmaceutical Excipients (Edited by: Kibbe AH, Washington, DC) American Pharmaceutical Association 2000, $91-93$

63. Caram-Lelham N, Sundelof LO: The effect of hydrophobic character of drugs and helix-coil transition of $\kappa$-carrageenan on the polyelectrolyte-drug interaction. Pharm Res 1996, 13:920925

\section{Pre-publication history}

The pre-publication history for this paper can be accessed here:

http://www.biomedcentral.com/1471-2334/2/27/prepub
Publish with BioMed Central and every scientist can read your work free of charge

"BioMed Central will be the most significant development for disseminating the results of biomedical research in our lifetime. "

Sir Paul Nurse, Cancer Research UK

Your research papers will be:

- available free of charge to the entire biomedical community

- peer reviewed and published immediately upon acceptance

- cited in PubMed and archived on PubMed Central

- yours - you keep the copyright

Submit your manuscript here:

http://www.biomedcentral.com/info/publishing_adv.asp
BioMedcentral 